\title{
A Administração da Justiça no Direito Romano
}

\author{
A. Santos Justo \\ Professor catedrático da Faculdade de Direito da \\ Universidade de Coimbra (Portugal) \\ sjusto@fd.uc.pt
}

Sumário: 1. Preliminares. 2. O processo das fórmulas. 3. O processo da cognição extraordinária. 4. Responsabilidade. 5. Honorários. Conclusões.

Resumo: A administração da justiça constituiu, ao longo da história, um problema que preocupou a humanidade. Não se estranhará, portanto, que a mãe do direito (Roma) lhe tenha dedicado a sua ciência (iurisprudentia). Mantendo a estrutura do antigo sistema das acções da lei (legis actiones), o processo das fórmulas (agere per formulas), utilizado na época clássica, colocou o magistrado romano (sobretudo o pretor) no centro da actividade processual, presidindo à fase (in iure) onde se declarava o direito (ius dicere), reservando ao juiz, que preside à segunda fase (apud iudicem), as tarefas probatória e decisória (a condenação ou a absolvição). Mais tarde, com a introdução do novo sistema processual (cognitio extra ordinem), aquelas fases foram concentradas, sendo agora desempenhadas por um magistrado, com a possibilidade de recurso das suas sentenças. Assinalam-se várias preocupações: v.g., com a competência dos tribunais, a celeridade processual, a isenção do juiz, o afastamento das partes que agissem temerariamente, a citação do demandado e os seus efeitos, a presença dos Santos Evangelhos nas salas de audiência, a disciplina e o valor dos diversos meios probatórios, os requisitos formais das sentenças e a faculdade de serem impugnadas etc. Destaca-se, também, a responsabilidade do juiz, que constituiu um quase-delito. Finalmente, impõe-se uma referência à associação dos advogados e à sua remuneração, que não se considera um preço (salarium merces), mas um honorarium, espécie de compensação ligada à honra das funções exercidas.

Palavras-chave: Direito Romano. Administração. Justiça. 


\section{PRELIMINARES}

Impõe-se uma nota prévia: este trabalho dirige-se fundamentalmente a quem não é cultor do saber jurídico romanista ${ }^{1}$. Por isso, justifica-se que o limitemos aos dois últimos processos, denominados, respectivamente, agere per formulas e cognitio extra ordinem.

A função que o juiz desempenhou no direito romano exige que o situemos nos processos que sucessivamente disciplinaram o julgamento dos litígios nas diferentes épocas: o processo das acções da lei (época arcaica), o processo das fórmulas (época clássica) e o processo da cognição extraordinária (épocas pós-clássica e justinianeia)². Mas exige também uma referência, embora breve, à actividade das partes.

Procuraremos, também, evitar os problemas que são apanágio da romanística e daremos a visão de um direito que, tendo vários séculos, constitui o laboratório onde se formou e continuará a formar o jurista autêntico: o que procura no passado a melhor compreensão do presente.

\section{PROCESSO DAS FÓRMULAS}

Introduzido em Roma por efeito do costume e mais tarde legalizado pela lex A ebutia de formulis, do ano 130 a.C. $\mathrm{C}^{3}$, este processo tem por elemento fundamental um documento escrito pelo pretor e dirigido ao juiz, através do qual este era autorizado a proferir uma sentença de condenação ou de absolvição, consoante provasse ou não os factos aí referidos.

Esse documento, denominado formula processual ${ }^{4}$, mostra-nos que, como já no sistema anterior, o novo processo decorria em dois momentos ou fases: a primeira, denominada in iure, era presidida pelo pretor (nas causas cíveis) que, depois de ouvir o demandante e o demandado e, na hipótese de não denegar a pretensão daquele, definia os termos do litígio e declarava solenemente o direito. Depois, na segunda fase, denominada apud iudicem, o juiz fazia a prova dos factos e proferia a sentença de condenação ou de absolvição. Actuando assim, o juiz limitava-se a cumprir a ordem que o pretor lhe dirigia na fórmula.

\footnotetext{
${ }^{1}$ Com o presente estudo participamos na homenagem prestada ao doutor Agerson Tabosa Pinto, o colega ilustre, a quem devemos a amizade autêntica.

2 Vide A. SANTOS JUSTO, Direito privado romano - I. Parte geral (Introdução. Relação jurídica. Defesa dos direitos3 em Studia Iuridica 50 (Coimbra Editora / Coimbra, 2006) 288-289, 307-312 e 388392. Sobre estas épocas, vide Sebastião CRUZ, Direito romano (Ius Romanum) I. Introdução. Fontes4 (Ed. do Autor / Coimbra, 1984) 43-51; e SANTOS JUSTO, A evolução do direito romano no Boletim da Faculdade de Direito. Volume comemorativo do $75^{\circ}$. tomo (2003) 47-68.

${ }^{3}$ Vide A. SANTOS JUSTO, Direito privado romano - I. Parte geral, cit. 307-311.

${ }^{4}$ Vide SANTOS JUSTO, ibidem 311-312.
} 
Elaborado este brevíssimo quadro, perguntar-se-á: que garantias eram dadas às partes? Que faculdades eram concedidas ao juiz?

Em relação às garantias, importa referir que o juiz era um cidadão romano de reconhecida idoneidade moral e cívica ${ }^{5}$. O seu nome figurava numa lista que o pretor oferecia às partes para, aí, escolherem o juiz que merecesse a sua confiança ${ }^{6}$. Ou seja, o juiz era, necessariamente, um homem da confiança do pretor e das partes. Portanto, as garantias começavam na escolha do juiz?

Se os litigantes não o escolhessem, o pretor nomearia o juiz que, no entanto, podia recusar se entendesse que não gozava da sua confiança ${ }^{8}$. Depois, na eventualidade normal de as partes o terem escolhido, o pretor controlava a sua actividade, podendo fixar um termo judiciário, prolongar ou suspender o processo e afastar e substituir o juiz ${ }^{9}$.

Importa sublinhar que o pretor tinha particular interesse na boa administração da justiça, quer porque dela dependia a sua progressão no cursus honorum ${ }^{10}$, quer porque as suas decisões podiam ser susceptíveis de recurso para os comitia (provocatio ad populum), quer porque podia incorrer, ainda, em responsabilidade se actuasse contra a lei ${ }^{11}$. Por isso, o pretor socorria-se necessariamente do apoio da jurisprudência que Ulpiano definiu lapidarmente como a "ciência do justo e do injusto, tendo como pressuposto o conhecimento de certas coisas divinas e humanas".

Ainda em relação ao juiz, era obrigado, antes do julgamento, a prestar juramento de que agiria segundo a verdade. E, no fim, podia abster-se de julgar, jurando que o litígio não tinha ficado claro $^{13}$.

Depois, há uma última garantia: se o juiz fosse negligente, incorria em responsabilidade por danos causados, considerando-se que praticou um quase-delito ${ }^{14}$. Não havia recurso da sentença porque as partes tinham escolhido o juiz, acordaram em respeitar a sua sentença e porque o pretor tinha vigiado a actividade do homem idóneo e da sua confiança.

\footnotetext{
${ }^{5}$ Vide Edward SZYMOSZEK, Les garanties de l’impartialité du juge dans le procés romain em Sodalitas. Scritti in onore di António Guarino 6 (Editore Jovene / Nápoles 1984) 2679-2680.

${ }^{6}$ Vide SZYMOSZEK, ibidem 2680

7 Sobre os impediementos do juiz, vide Carlo LANZA, Impedimenti del giudige. Alcuni modelli di "diritto clássico" no Bulletino dell'Istituto di Diritto Romano XC (1987) 467-541.

${ }^{8}$ Vide SZYMOSZEK, ibidem 2678.

${ }^{9}$ Vide SZYMOSZEK, ibidem 2681-2682.

${ }^{10}$ Vide CRUZ, o.c. 65-66; e SANTOS JUSTO, Direito privado romano - I. Parte geral, cit. 62-63.

${ }^{11}$ Vide SANTOS JUSTO, ibidem 65.

${ }^{12} \mathrm{D}$. 1,1,10,2: "Iurisprudentia est divinarum atque humanarum rerum noticia (,) iusti atque iniusti scientia". Sobre a iurisprudentia, vide CRUZ, o.c. 280-295; e SANTOS JUSTO, ibidem 86-91.

${ }^{13}$ Vide SZYMOSZEK, ibidem 2682.

${ }^{14}$ Cf. D. 44,7,5,4; -50,13,6.
} 


\section{PROCESSO DACOGNIÇÃO EXTRAORDINÁRIA}

\subsection{ORIGEM}

A origem do processo da cognitio extra ordinem relaciona-se com a transformação do sistema político que se impôs, em Roma, a partir de Augusto: o Principado que, no ano 27 a.C., substituiu a República. Mais precisamente, foi no dia 13 de Janeiro desse ano que, numa memorável sessão do Senado, Octávio declarou o seu propósito de regressar à vida privada, depois de ter concluído a sua obra de cônsul: o assassínio de César está vingado e a ordem, restabelecida. O Senado pediu-lhe que continuasse e atribuiu-lhe o título de Augustus, a que se seguiu a concessão do imperium proconsolare maius ${ }^{15}$.

Octávio passou a ocupar o primeiro lugar. Tornou-se o princeps romanorum e, embora formalmente mantidas, as velhas magistraturas foram perdendo a sua importância, acabando por se tornar simples títulos honoríficos. A administração burocratizou-se com novos funcionários que dependem directamente do Imperador: uns governam as províncias e comandam as legiões (legati); outros representam-no em matérias determinadas (prafectus urbi, praefectus annonae, prafectus vigilum, praefectus praetorio); outros substituem os antigos questores e edis (curatores); e outros administram a fazenda pública (procuratores). A função jurisdicional foi atribuída a estes funcionários ${ }^{16}$, no âmbito das suas competências: policiar a civitas; abastecê-la de géneros alimentícios; exercer a vigilância nocturna; e chefiar o quartel-general e a guarda especial do Imperador.

Porém, o princeps não dispensa a assessoria de jurisconsultos eminentes e de titulares de cargos elevados que constituem o seu consilium e cujas funções se relacionam, sobretudo, com a sua actividade legislativa e jurisdicional.

Na época anterior da República, tinha-se imposto o processo das fórmulas que, já referimos, decorria em dois momentos: primeiro, na presença do pretor que declarava o direito (ius dicere); depois, perante um juiz escolhido, em regra, pelas partes, que proferia a sentença depois da actividade probatória. Agora, surge um novo processo em que a administração da justiça é confiada ao Imperador ou os seus funcionários em quem delega, que apreciam e resolvem determinados litígios: é a cognitio que, de extraordinaria, se expandiu até substituir o velho processo das fórmulas ${ }^{17}$.

O Estado chamou a si a tarefa de proteger o direito e defender a paz e, em consequência, o novo processo assumiu uma dimensão pública que contrasta com o carácter privado do velho processo das fórmulas: de privada, a justiça tornou-se pública ${ }^{18}$.

\footnotetext{
${ }^{15}$ Sobre o Principado, vide CRUZ, o.c. 72-76; e SANTOS JUSTO, ibidem 67-69.

${ }^{16}$ Vide Francesco DE MARTINO, "Litem suam facere" em BIDR XCI (1988) 22-23.

${ }^{17}$ Vide SANTOS JUSTO, ibidem 388-392.

${ }^{18}$ Vide SANTOS JUSTO, ibidem 391.
} 
Afastada a escolha do juiz pelas partes, impunha-se a criação de uma nova garantia: a possibilidade de o recusarem sem dilatarem excessivamente a duração do processo.

Assim, no ano 331, o Imperador Constantino proibiu que, depois da contestação, se questionasse a competência do tribunal e recorresse, antes do tempo, para o prefeito do pretório, o conde do Oriente ou outro respeitável juiz. Mas concedeu-lhes a faculdade de recorrerem ao sacro tribunal (sacrum auditorium) ${ }^{19}$.

Depois, já no tempo de Justino ou de Justiniano ${ }^{20}$, foi reafirmada a necessidade de os magistrados e "divinos juízes" decidirem os litígios em breve prazo; por isso, se o juiz competente se atrasasse sem justa causa, o interessado podia dirigir-se ao Imperador. E se alguém recusasse o juiz por justa causa, antes e só antes da contestação da demanda, dar-se-lhe-ia outro juiz ${ }^{21}$.

No ano 530, Justiniano reconheceu este direito de os litigantes recusarem os juízes antes do início do processo. O pedido, que devia ser suportado em motivos sérios sob pena de rejeição ${ }^{22}$, era dirigido ao Imperador que designava outro juiz. Depois de este iniciar a sua actividade, não podia ser recusado para que os litígios não se prolongassem indefinidamente ${ }^{23}$. A preocupação do Imperador era afastar dúvidas sobre a isenção do juiz e, ao mesmo tempo, evitar que os processos se arrastassem por tempo considerado excessivo.

Finalmente, no ano 537, foi dilatada para vinte dias após a entrega do libelo (que dava início ao processo) a possibilidade de o juiz ser recusado. Depois, a parte interessada só podia apelar ao Imperador para que anulasse o julgamento do juiz parcial $^{24}$. Se a recusa fosse deferida, o novo juiz não podia ser recusado ${ }^{25}$.

Quanto aos litigantes, eram obrigados a prestar juramento de que não agiam temerariamente e quem perdesse o litígio respondia pelas despesas processuais; institucionalizou-se a appelatio da sentença para um funcionário superior, dito magistrado ${ }^{26}$; o consilium principis adquiriu especial importância na função de assessoria jurídica ${ }^{27} \mathrm{e}$, embora se mantivesse o princípio da oralidade, o documento escrito foi-se impondo paulatinamente por influência oriental ${ }^{28}$.

\footnotetext{
${ }^{19}$ Cf. C. 3,13,4.

${ }^{20}$ Vide SZYMOSZEK, ibidem 268538.

${ }^{21}$ Cf. C. 1,3,12.

${ }^{22}$ Vide SZYMOSZEK, ibidem 2685.

${ }^{23}$ Cf. C. 3,1,16.

${ }^{24}$ Cf. N. 53,3,1.

${ }^{25}$ Cf. N. 53,3,4.

${ }^{26}$ Vide SANTOS JUSTO, ibidem 409-411.

${ }^{27}$ Vide SANTOS JUSTO, ibidem 405.

${ }^{28}$ Vide SANTOS JUSTO, ibidem 401.
} 
Nos primeiros tempos, o magistrado-juiz gozou de ampla liberdade e, por isso, a cognitio extra ordinem constitui um instrumento poderoso da criação de um ius novum ao lado das constitutiones imperiais ${ }^{29}$.

\subsection{TRAMITAÇÃO}

\subsubsection{CITAÇÃO}

Inicialmente, o processo (a que nos referimos) começava com a citação do demandado que continha a ordem do magistrado para comparecer perante ele. Podia ser feita verbalmente, se o demandado estivesse presente; por escrito, se se encontrasse ausente; e por éditos se o seu domicílio fosse ignorado. Nesta hipótese, um pregoeiro lia-os em locais públicos e, mais tarde, eram fixados em locais determinados. A citação verbal e por escrito podia ser repetida quatro vezes com intervalos de dez dias e a última continha a cominação de que, se o demandado não se apresentasse, o processo tramitaria e seria decidido sem a sua presença. Neste caso, não podia apelar da sentença ${ }^{30}$.

Na época de Justiniano (século VI) impôs-se uma nova modalidade de citação, denominada "procedimento por libelo". O demandante apresentava ao magistrado um documento assinado, no qual expunha a sua pretensão, os fundamentos em que a apoiava, indicava o nome da acção (actio) que se propunha intentar e pedia-lhe protecção jurídica. Dirigia-lhe igualmente uma postulatio para que ordenasse a entrega, ao demandado, duma cópia do libelo e a sua citação para comparecer no tribunal; e prometia que continuava o processo até o fim e pagaria os gastos se a sentença fosse desfavorável. O magistrado examinava brevemente aquele documento (libellus) e, se não recusasse o pedido, emitia um decreto ordenando a um funcionário (executor) que o libelo fosse entregue ao demandado e este citado para comparecer, num dia determinando, perante ele. Feita a citação, o demandado entregava ao executor um documento (libellus contradictionis) contendo a data da entrega do libelo e a sua posição perante a pretensão do demandante. Ao mesmo tempo prestava uma garantia (cautio iudicio sisti) de que estaria na presença do magistrado no dia fixado e de que não abandonaria o processo até a sentença. Se não prestasse a caução, ficava sujeito à vigilância do executor durante a tramitação do processo e podia ser preso num cárcere do Estado ${ }^{31}$.

\footnotetext{
${ }^{29}$ Sobre as constituições imperiais e o ius novum ou extraordinarium, vide SANTOS JUSTO, ibidem 44-45 e 84-86.

${ }^{30}$ Cf. C. 7,65,1. Vide SANTOS JUSTO, ibidem 392-393.

${ }^{31}$ Vide SANTOS JUSTO, ibidem 393-394.
} 
Entretanto, o executor entregava o libellus contradictionis ao demandante e, entre a data da citação e o dia fixado para o demandado comparecer perante o magistrado, deviam decorrer, pelo menos, dez dias, prazo que Justiniano dilatou para vinte ${ }^{32}$.

\subsubsection{EFEITOS DA CITAÇÃO}

A citação do demandado produzia vários efeitos ${ }^{33}$, de que destacamos:

1. fixava a relação litigiosa e justificava a situação de litis pendentia: enquanto a lis pender, o demandante não podia intentar nova acção $0^{34}$;

2. o demandado era obrigado a contestar o libelo, sob pena de incorrer em contumácia ${ }^{35}$;

3. fixava definitivamente o forum ${ }^{36}$;

4. a relação litigiosa não era afectada por actos posteriores: v.g., se a prestação se tornasse impossível sem culpa do devedor demandado ou se a res perecesse, este continuava obrigado;

5. dava início ao prazo de dois meses para o demandante comparecer junto do magistrado para continuar o processo;

6. interrompia a prescrição ${ }^{37}$;

7. fazia cessar a boa fé do possuidor da herança, tratando-se de hereditatis petitio ${ }^{38}$.

\subsubsection{ACTUAÇÃO PERANTE O MAGISTRADO}

\subsubsection{JULGAMENTO}

Importa desde já referir que uma lei de Leão, do ano 469, determinou que, nas sessões do tribunal, deviam ser expostos os Santos Evangelhos ${ }^{39}$. E Justiniano aplicou esta disposição que, no procedimento contumaz procurava também suprir a ausência do litigante pela presença de Deus ${ }^{40}$. Os Santos Evangelhos deviam permanecer expostos até a pronúncia da sentença, porque "atentos às Sagradas Escrituras e consagrados pela presença de Deus, os juízes decidirão os litígios com maior apoio, não julgam os outros diferentemente do que são julgados porque o juízo é mais terrível para eles do que para as partes”41.

\footnotetext{
${ }^{32}$ Cf. N. 53,3,1. Vide SANTOS JUSTO, ibidem 394.

${ }^{33}$ Vide SANTOS JUSTO, ibidem 397-398.

${ }^{34}$ Cf. D. 5,1,30; -5,1,34; C. 2,2,4pr.; -2,2,4,2; -7,17,1,3.

${ }^{35}$ Cf. C. $1,16,6,4$.

${ }^{36}$ Cf. C. $2,2,4,1$.

${ }^{37}$ Cf. C. 7, 40,3,3.

${ }^{38}$ Cf. D. 5,3,20,11; -5,3,25,7.

${ }^{39}$ Cf. C. $11,32,3,2$.

${ }^{40}$ Cf. C. $3,1,13,4$.

${ }^{41}$ Cf. C. $3,1,14,2$.
} 
Na presença do magistrado, o demandado podia reconhecer a verdade dos factos alegados pelo demandante, embora esta confessio constituísse simples meio de prova. Se reconhecesse o direito invocado pelo demandante, produzia um efeito semelhante ao da sentença condenatória e, portanto, tinha valor executivo: confessio in iure pro iudicato est ${ }^{42}$.

Se o demandado não confessasse, o demandante devia jurar, sobre os Evangelhos, de que actuava de boa-fé, convencido de que a sua pretensão é perfeitamente fundada. Seguia-se igual juramento do demandado. Ambos prometiam, ainda, que não realizariam nenhum acto processual doloso ${ }^{43}$; e juravam igualmente que não fizeram nenhuma doação ao juiz para que a sentença lhes fosse favorável ${ }^{44}$. Se um dos litigantes tivesse feito esta doação, perdia o processo mesmo que a sua pretensão fosse justificada ${ }^{45}$. Juramento semelhante era prestado pelos advogados e o próprio juiz jurava que decidiria o litígio de acordo com a verdade e as leis ${ }^{46}$.

Seguiam-se o debate contraditório, cujo início constituía o ponto de partida para a contagem do prazo de três anos fixado para a duração máxima do processo ${ }^{47}$; e o período probatório, no qual as partes deviam provar a verdade das suas alegações. No entanto, a prova obedecia às seguintes normas ${ }^{48}$ :

1. reflectindo a evolução política e jurídica, a liberdade do antigo juiz privado (do processo das fórmulas) na valoração da prova foi-se atenuando progressivamente, impondo-se o sistema da prova legal;

2. a prova documental prefere sobre a prova testemunhal, afirmando-se que "contra um testemunho escrito não se apresenta um não escrito"

3. o magistrado pode recorrer a outros meios de prova (v.g., peritos) se os considerar necessários à formação da sua convicção ${ }^{50}$;

4. o onus probandi incumbe a quem pretende retirar consequências favoráveis: ao demandante, para fundamentar a sua pretensão; ao demandado, para sustentar uma reconvenção ou exceptio. No entanto, mantém-se o antigo princípio de que, para ser absolvido numa acção de reivindicação, ao possuidor demandado basta que o demandante não prove o direito que alega. Estamos perante a probatio diabolica de que falam os juristas medievais ${ }^{51}$;

\footnotetext{
${ }^{42}$ Cf. D. 42,2,1; PS II, 1,5.

${ }^{43}$ Cf. C. 2,58(59),2pr.; -3,1,14,4; N. 49,3.

${ }^{44}$ Cf. N. 124.

${ }^{45}$ Cf. D. $12,5,2,2 ;$ C. $7,49,1$.

${ }^{46}$ C. C. $3,1,14$.

${ }^{47}$ Se este prazo decorresse sem o processo ter terminado, o iudicium caducava e os actos processuais realizados eram anulados: C. 3,1,13,1.

${ }^{48}$ Vide SANTOS JUSTO, ibidem 400-402.

${ }^{49}$ Cf. C. $4,20,1$.

${ }^{50}$ Cf. D. 11,1,21; C. 3,1,9; C. Th. II,18,1.

${ }^{51}$ Vide SANTOS JUSTO, Direitos reais (Coimbra Editora / Coimbra, 2007) 279.
} 
5. a prova deve versar sobre factos, considerando-se que o magistrado-juiz deve conhecer o direito aplicável. As partes não deixavam, no entanto, de apresentar as opiniões de jurisconsultos, lidas por um funcionário. É provável que, a partir de Trajano, se tenha formado a convicção de que as opiniões de jurisconsultos distinguidos com o ius publice respondendi ex auctoritate principis ${ }^{52}$ têm força vinculativa. Segundo GAIUS, Adriano confirmou este ponto de vista, gozando o juiz de liberdade para proferir a sentença como entender somente se essas opiniões não coincidirem ${ }^{53}$. Mais tarde, a Lei das Citações, promulgada por Valentiniano III no ano 426, limitou os juristas a Gaius, Papinianus, Paulus, Ulpianus e Modestinus e a quem estes citassem. Havendo discordância, o juiz deve seguir a maioria; no caso de empate, impor-se-á a opinião de PAPINIANUS; e se esta não for conhecida, o juiz é livre ${ }^{54}$.

Quanto aos meios de prova, referimos ${ }^{55}$ :

1. a confessio das partes quando versasse sobre factos;

2. o juramento necessário (iusiurandum necessarium): podia ser deferido pelo demandante ao demandado, em situações determinadas (v.g., negócios de direito estrito, reivindicação de coisa certa, nos pactos que fixavam o dia do pagamento da dívida, na acção de injúrias etc.), podendo o demandado tomar uma de quatro posições:

a) pagava a dívida;

b) fazia o juramento e o litígio ficava resolvido a seu favor ${ }^{56}$;

c) recusava o juramento e, nesta hipótese, era obrigado pelo pretor a cumprir a obrigação por que era demandado: condenava-se a si próprio ${ }^{57}$. Nas palavras de PAULUS, "é prova de torpeza manifesta e de confissão não querer jurar nem contradeferir o juramento"

d) provocava o demandante a prestar juramento. Nesta hipótese, o demandante podia:

${ }^{52}$ Vide SANTOS JUSTO, A fictio iuris no direito romano (actio fictícia). Época clássica I no suplemento do vol. XXXII do BFD (1988) 161-185.

${ }^{33}$ Cf. GAIUS 1,7 .

${ }^{54}$ Cf. C. Th. $1,4,3$.

${ }^{55}$ Vide SANTOS JUSTO, Direito privado romano - I. Parte geral, cit. 402-404.

${ }^{56}$ Dir-se-á, neste caso, que o juramento equivale à sentença: tem função decisória; ou que, por vontade do demandante, o demandado converte-se em juiz do litígio. Cf. D. 44,5, lpr.

${ }^{57}$ Cf. D. 12,2,34,6.

${ }^{58}$ Cf. D. $12,2,38$ 
1. prestar o juramento de que era credor. O litígio era decidido a seu favor ${ }^{59}$;

2. recusar o juramento. O litígio era resolvido a favor do demandado.

O recurso a este juramento, dito necessário, apoiava-se na sua santidade, como refere o jurisconsulto Gaius ${ }^{60}$. Por isso, se quem jurasse viesse a ser condenado por perjúrio, incorria na nota de infamia ${ }^{61}$ : era considerado indigno e, em consequência, não podia nomear nem ser nomeado procurador judicial, desempenhar cargos públicos, testemunhar, intentar uma acção popular etc ${ }^{62}$.

3. as declarações de testemunhas. No entanto, o seu valor foi desvalorizado por desconfiança e por influência oriental que destacou o valor da prova escrita. Impuseram-se as seguintes normas ${ }^{63}$ :

a) a declaração de uma só testemunha carece de valor probatório, qualquer que seja a sua posição social e a credibilidade que mereça ${ }^{64}$;

b) tem mais valor a declaração da testemunha de elevada posição social;

c) nos litígios contra cristãos, não se deve outorgar fé às declarações de hereges e judeus $^{65}$.

4. a prova documental adquiriu uma importância primária. Distinguiam-se os documentos ${ }^{66}$ :

a) redigidos por oficiais públicos, faziam prova plena e perpétua dos factos e declarações registadas, embora o seu conteúdo pudesse ser impugnado por falsidade. Denominavam-se acta ou gesta;

b) instrumentos públicos redigidos no forum por tabeliões que, embora não fossem considerados funcionários públicos, desenvolviam uma actividade sujeita à vigilância dos magistrados e às determinações legais. Estes documentos faziam fé se o tabelião os confirmasse por juramento na presença do magistrado e denominavam-se instrumenta publica;

\footnotetext{
${ }^{59} \mathrm{~V}$ Cf. D. $42,1,56$.

${ }^{60}$ Cf. D. 12,2,1.

${ }^{61}$ Cf. D. 12,2,9,2.

${ }^{62}$ Vide SANTOS JUSTO, ibidem 145-147.

${ }^{63}$ Vide SANTOS JUSTO, ibidem 403

${ }^{64}$ Cf. C. 4,20,4; N. 4,20,9.

${ }^{65}$ Cf. C. $1,5,21 \mathrm{pr}$.

${ }^{66}$ Vide SANTOS JUSTO, ibidem 403-404.
} 
c) documentos privados, redigidos por particulares. Se interviessem pelo menos três testemunhas, eram considerados documentos quase públicos e tinham o mesmo valor probatório dos documentos redigidos por tabeliões ${ }^{67}$. Denominavam-se chirographa;

5. prova pericial: o magistrado-juiz podia recorrer a calígrafos, agrimensores, médicos e parteiras etc.

Durante o julgamento, as partes procuravam, em regra, a assistência e o auxílio de jurisconsultos que as aconselhassem na condução do processo; e de oradores que por elas falassem nos debates. Aqueles davam as suas opiniões sobre as questões jurídicas; os oradores eram escolhidos pelas suas qualidades oratórias ou pela sua elevada posição social ${ }^{68}$.

Participavam, ainda, peritos em questões jurídicas ou pessoas de grande prestígio que acompanhavam as partes, confortando-as com a sua presença e conselhos. Denominavam-se advocati e acabaram por substituir os oradores, incapazes de trabalho eficaz por não terem conhecimentos jurídicos.

\subsubsection{SENTENÇA}

\subsection{CARACTERIZAÇÃO}

Feita a prova, o juiz consultava os seus adsessores e, depois de considerar as opiniões dos jurisconsultos que as partes tivessem apresentado em documento escrito selado por testemunhas $\left(\right.$ testatio) ${ }^{69}$, proferia a sentença.

No entanto, podia remeter a resolução ao Imperador se considerasse o caso duvidoso e entendesse oportuno não decidir ${ }^{70}$.

A sentença obedecia a requisitos formais de que destacamos a redacção de um libelo que o próprio juiz lia às partes, não podendo o texto ser posteriormente modificado ${ }^{71}$. As partes deviam ser citadas, mas a sua ausência não invalidava a sentença $^{72}$, que devia ser clara e precisa, sob pena de não ter força jurídica ${ }^{73}$.

\footnotetext{
${ }^{67}$ Cf. C. 8,17(18),11; N. 73,2.

${ }^{68}$ Vide SANTOS JUSTO, ibidem 285-288.

${ }^{69}$ Cf. D. 1,2,2,49. Vide SANTOS JUSTO, ibidem 405.

${ }^{70}$ Vide SANTOS JUSTO, ibidem 406.

${ }^{71}$ Cf. D. 7,44,2pr.

${ }^{72}$ Cf. C. $7,43,2$.

${ }^{73}$ Cf. C. 7,46,3-4.
} 
O juiz podia condenar numa certa res, se fosse objecto da actio ou numa quantia pecuniária $^{74}$. Neste caso, dever-se-ia ter em conta o interesse do demandante ${ }^{75}$. E devia indicar a parte condenada nas custas processuais, sob pena de as ter de pagar ${ }^{76}$.

\subsection{IMPUGNAÇÃO}

Da passagem da administração da justiça a função estatal resulta que a sentença proferida num processo da extraordinaria cognitio tornou-se susceptível de recurso para um magistrado de categoria superior.

Diferentemente do que ocorria no velho processo das fórmulas, no qual as partes não podiam recorrer da sentença do juiz porque tinham acordado sujeitar-se-lhe, era agora possível:

1. apelar duma sentença definitiva, salvo no procedimento contumaz $z^{77}$. O apelo (appellatio) era dirigido ao magistrado imediatamente superior e, se fosse necessário, seguir-se-ia a ordem hierárquica até o Imperador ${ }^{78}$.

Num prazo breve $^{79}$,o recorrente devia apresentar o seu apelo ao juiz que proferiu a sentença. Tinha efeito suspensivo, impedindo, portanto, a sua execução. Aquele juiz devia abster-se de coagir as partes para que não apelassem e, se recusasse a apelação, o recorrente podia dirigir-se ao magistrado superior que podia impor uma pena pecuniária ao juiz recorrido e ao recorrente, se considerasse, respectivamente, adequada ou não a apelação ${ }^{80}$.

Se a apelação fosse admitida, o juiz redigia uma exposição sobre a questão litigiosa. O processo era encaminhado para o magistrado superior e tudo se passava como se tratasse de um novo processo: repetiam-se os debates, podiam apresentar-se novas provas, aduzir novos factos e fundamentar diferentemente a questão litigiosa. No entanto, devia aplicar-se o direito vigente durante a litis pendentia da primeira instância ${ }^{81}$.

O processo de apelação devia ser decidido num prazo que oscilou entre um e dois anos, decorridos os quais a instância caducava e a sentença do juiz inferior se considerava firme.

\footnotetext{
${ }^{74}$ Cf. I. 4,6,32.

${ }^{75}$ Cf. D. $6,1,68 ;-42,1,13,1 ;-42,2,3, ;$ I. 4,6,32.

${ }^{76}$ Cf. C. 7,51,5. Vide SANTOS JUSTO, ibidem 407.

${ }^{77}$ Cf. C. $7,65,1$.

${ }^{78}$ Vide SANTOS JUSTO, ibidem 409.

${ }^{79}$ Dois ou três dias úteis no Código (C. 7,62,6,5) e no Digesto (D. 49,1,5,4); e dez dias contínuos nas Novelas (N. 23,1).

${ }^{80}$ Vide SANTOS JUSTO, ibidem 410.

${ }^{81}$ Cf. G. 7,62,6pr.; N. 115,1. Vide SANTOS JUSTO, ibidem 410.
} 
Se o apelante perdesse, devia pagar ao apelado o quádruplo das custas processuais que tivesse pago $^{82}$. O apelante temerário incorria em uma sanção pecuniária que o magistrado devia fixar, tendo em conta as circunstâncias do caso e a maior ou menor temeridade ${ }^{83}$.

2. suplicar ao Imperador que, no entanto, costumava encarregar o prefeito do pretório de reexaminar o litígio. Tratava-se, portanto, de uma verdadeira revisão da sentença pela mesma autoridade que a proferiu. A supplicatio tinha efeito suspensivo, se fosse interposta no prazo de dez dias ${ }^{84}$. No entanto, a outra parte podia solicitar a execução da sentença se apresentasse fiadores para o caso de a revisão a modificar ${ }^{85}$.

\subsection{EFEITOS}

Se não houvesse impugnação ou, havendo-a a sentença fosse confirmada, esta produzia os mesmos efeitos que outrora se verificavam no antigo processo das fórmulas.

Esses efeitos denominam-se ${ }^{86}$ :

1. negativo ou de exclusão: o demandante não podia voltar a intentar a mesma actio, sendo indiferente que a sentença lhe fosse favorável ou desfavorável. Se fosse instaurada nova actio, o magistrado recusá-la-ia oficiosamente através duma denegatio actionis;

2. positivo: traduzia-se na autoridade do caso julgado e tinha carácter material: o que foi dito na sentença impunha-se como verdade entre as partes; por isso, a sentença podia ser invocada e devia ser respeitada.

Da conjugação dos dois efeitos resultava o princípio bis de eadem re ne sit actio, segundo o qual era impossível não só instaurar duas vezes a mesma actio, mas também uma actio distinta sobre o mesmo assunto (eadem res, eadem quaestio).

E retiravam-se duas modalidades de caso julgado:

1. formal: não era possível voltar a discutir a sententia nem atacá-la de novo num processo ordinário;

\footnotetext{
${ }^{82} \mathrm{C}$ Cf. PS V,37.

${ }^{83}$ Cf. C. $3,1,13,6 ;-7,62,6,4$.

${ }^{84}$ Cf. N. 23,1.

${ }^{85}$ Vide SANTOS JUSTO, ibidem 411.

${ }^{86}$ Vide SANTOS JUSTO, ibidem 412.
} 
2. material: a sentença proferida resolvia definitivamente a questão litigiosa entre as partes; por isso, qualquer delas podia invocá-la se, no futuro, voltasse a pôr-se entre elas a mesma questão litigiosa.

Outro efeito era a possibilidade de a sentença ser executada, através duma acção executiva denominada actio iudicati, que se intentava junto do magistrado que proferiu a sentença ou delegou noutro juiz. Diferentemente do que ocorria no processo antigo das fórmulas, a condenação pecuniária não constituía, agora, um requisito indispensável: também podia incidir sobre a própria coisa (in natura) ou na realização de um acto (facere) ${ }^{87}$.

E, via de regra, tinha carácter patrimonial. Embora subsista, a execução pessoal foi atenuada a partir do século IV. Assim, além de passar a fazer-se em cárceres públicos $^{88}$, foi concedida ao executado a possibilidade de a substituir pela cedência de bens (bonorum cessio) ${ }^{89}$.

Ademais, os credores podiam acordar na redução do montante dos seus créditos para facilitar o pagamento ao devedor ${ }^{90}$ e conceder-lhe uma moratória de cinco anos para pagar as dívidas ${ }^{91}$, moratória que o devedor também podia pedir ao Imperador ${ }^{92}$.

Finalmente, não havia lugar para a execução pessoal se o devedor jurasse que não possuía bens ${ }^{93}$.

\section{RESPONSABILIDADE}

Durante o antigo processo das fórmulas, o pretor, que declarava o direito na primeira fase (in iure), era um magistrado romano que detinha os poderes de potestas, imperium eiurisdictio: com o primeiro, representava o povo romano; com o segundo, tinha o poder de soberania; e com o último, administrava a justiça de forma normal e corrente ${ }^{94}$.

${ }^{87}$ C Vide SANTOS JUSTO, ibidem 413-416; e A execução: pessoal e patrimonial (direito romano) em O Direito ano 125․ III-IV (1993) 298.

${ }^{88}$ Cf. C. 9,5,1. Vide SANTOS JUSTO, A execução: pessoal e patrimonial, cit. 282.

${ }^{89}$ Cf. D. 42,3,9; e C. Th. IV, 20,1 que, todavia, limita a bonorum cessio a devedores cuja insolvência tenha sido produzida por incêndio, naufrágio ou qualquer infortúnio. Vide SANTOS JUSTO, Direito privado romano - I: Parte geral, cit. 414.

${ }^{90}$ Bastava que participasse a maioria dos credores para que todos ficasse, vinculados. Vide SANTOS JUSTO, A execução: pessoal e patrimonial, cit. 299.

${ }^{91}$ Cf. G. 7,71,8. Vide SANTOS JUSTO, Direito privado romano - I. Parte geral, cit. 416-317; e A execução: pessoal e patrimonial, cit. 299.

${ }^{92}$ Cf. C. 7,71,8. Vide SANTOS JUSTO, Direito privado romano - I. Parte geral, cit.417.

${ }^{93}$ Cf. N. 135,1 .

${ }^{94}$ Vide Sebastião CRUZ, o.c. 66-67; e SANTOS JUSTO, ibidem 269-273. 
Enquanto magistrado, era eleito nas assembleias comiciais e, integrando o cursus honorum, o acesso à posição superior de cônsul dependia da forma como tivesse exercido as suas funções no ano para que fora eleito pretor. Já por aqui se vê o cuidado que este magistrado devia desempenhar nas suas funções ligadas à administração da justiça.

Acrescem, ainda, diversas limitações que se conjugavam na exigência de um bom desempenho: a duração do cargo não excedia, em regra, um ano; o magistrado hierarquicamente superior podia vetar as suas decisões (ius intercessionis); qualquer cidadão podia apelar aos comitia sobre uma pena ou castigo disciplinar que lhe fosse imposto (provocatio ad populum); e, no fim do exercício do cargo, podia responder pelos actos praticados contra a lex ${ }^{95}$.

Havia, portanto, instrumentos que asseguravam a boa administração da justiça: uns, políticos; outros, jurídicos.

Quanto ao juiz, era um cidadão romano que as partes escolhiam numa lista que o pretor lhes oferecia ou, recusando, impunha. Por isso, era naturalmente um homem justo e respeitado na sociedade romana ${ }^{96}$ e devia obedecer à ordem que, num documento escrito (fórmula), o pretor lhe dirigia para absolver ou condenar o demandado consoante provasse ou não os factos invocados pelo demandante. É provável que esta garantia de um juiz justo tenha sido anteriormente reforçada pela Lei das XII Tábuas que, segundo parece, sancionou, com a pena de morte, o juiz que se deixasse corromper, aceitando dinheiro para proferir uma sentença. $\mathrm{E}$ foi posteriormente fortalecida pelo pretor que impôs a obrigação de ressarcir as partes dos prejuízos causados, situação que levou a iurisprudentia a criar a figura do quase-delito do iudex qui litem suam fecit ${ }^{97}$.

Persistem dúvidas sobre esta figura, sendo comum a opinião de que incorria neste quase-delito o juiz que ditasse uma sentença injusta ${ }^{98}$. Há, no entanto, quem entenda que sancionava o juiz que: não obedecesse à ordem transmitida pelo pretor na fórmula processual a que se tinha vinculado ${ }^{99}$; ou não proferisse a sentença no tempo em que devia ${ }^{100}$, prejudicando o demandante com a caducidade da actio101. Há também quem considere que a responsabilidade do juiz era objectiva ${ }^{102}$ e quem entenda que tinha carácter subjectivo ${ }^{103}$.

${ }_{95}$ Vide SANTOS JUSTO, ibidem 65.

${ }^{96}$ Vide SZYMOSZEK, o.c. 2679-2680, que fala de representantes das classes mais elevadas da sociedade, onde inclui senadores e homens experimentados.

${ }^{97}$ Cf. D. 5,1,15,1. Vide Francesca LAMBERTI, Riflessioni in tema di "litem suam facere" em Labeo 36 (1990) 225 e 237; e SANTOS JUSTO, ibidem 419.

98 Vide Álvaro D’ORS, ”Litem suam facere" em SDHI XLVIII (1982) 368.

99 Vide Javier PARICIO, Notas sobre la sentencia del arbiter ex compromisso. Sanción contra el árbitro que no dió sentencia em RIDA XXXI (1984) 288.

${ }^{100}$ Nos iudicia legitima, era de 18 meses. Vide DE MARTINO, o.c. 14 e 19; PARICIO, o.c. 303; e LAMBERTI, o.c. 259-260.

${ }^{101}$ Vide D’ORS, o.c. 370 e 372; PARICIO, o.c. 289 e 303; e LAMBERTI, o.c. 234.

${ }^{102}$ Vide D'ORS, o.c. 390-393.

${ }^{103}$ Vide LAMBERTI, o.c. 244. 
Este quase-delito manteve-se no novo processo ${ }^{104}$. Não são estranhas a corrupção que se tinha instalado ${ }^{105}$, a burocratização da justiça, a crise dos costumes, a debilitação do poder central e outras causas que criaram um panorama desolador ${ }^{106}$. Por isso, os Imperadores proclamaram que os juízes deviam julgar segundo a justiça ${ }^{107}$ e convidaram as vítimas a deslocarem-se à capital para se queixarem directamente ao Imperador.

Incorria nesse quase-delito o iudex qui litem suam facit, ou seja, proferisse uma sentença injusta ${ }^{109}$ para alguma das partes: não a profere, não respeita o prazo, toma partido por uma das partes etc. Em consequência, era obrigado a reparar o dano causado $^{110}$, sem prejuízo de o lesado apelar para o magistrado superior, pedindo a correcção da sentença ${ }^{111}$. E bastava que o juiz fosse imprudente ${ }^{112}$, conceito em que Justiniano incluiu a ignorância do direito, por considerar muito grave o baixo nível dos estudos jurídicos ${ }^{113}$.

Além do quase-delito assinalado, o juiz que se deixasse corromper incorria na obrigação de ressarcir a parte lesada das custas processuais ${ }^{114} \mathrm{e}$, se julgasse contra a lei, na pena de desterro para uma ilha ${ }^{115}$.

Também os assessores incorriam em responsabilidade se aconselhassem dolosamente ou por negligência ${ }^{116}$.

$\mathrm{E}$ os advogados cometiam o delito de falsidade se entregassem à parte contrária documentos que lhes foram confiados pelos seus clientes ${ }^{117}$; e subornassem testemunhas para prestarem testemunho falso ${ }^{118}$.

\footnotetext{
${ }^{104} \mathrm{~V}$ Cf. I. 4,5pr.

${ }^{105}$ Vide DE MARTINO, o.c. 24.

${ }^{106}$ Cf. C. Th. I,16,7. Vide SANTOS JUSTO, ibidem 419.

${ }^{107}$ Cf. G. $7,62,6,1$.

${ }^{108}$ F. C. $12,61,1$.

${ }^{109}$ Vide D'ORS, o.c. 378-379.

${ }^{110}$ Vide LAMBERTI, o.c. 225 e 237; e SANTOS JUSTO, Direito privado romano - II (Direito das obrigações)2 em Studia Iuridica 76 (Coimbra Editora / Coimbra, 2006) 138.

${ }^{11}$ Vide DE MARTINO, o.c. 24.

${ }^{112}$ Vide DE MARTINO, o.c. 10 e 36; LAMBERTI, o.c. 264-266; e SANTOS JUSTO, ibidem 138.

${ }^{113}$ Vide DE MARTINO, o.c. 25.

${ }^{114}$ Cf. C. $3,1,13,6 ;-3,1,15$.

${ }^{115}$ Cf. D. 48,10,1,3; PS V,25,4.

${ }^{116}$ Cf. D. 2,2,2.

${ }^{117}$ Cf. D. 48,10,1,6; PS V,25,8.

${ }^{118}$ Cf. D. 48,10,1,2; PS V,25,2.
} 


\section{HONORÁRIOS}

Nos primeiros tempos, a ajuda prestada por oratores e advocati foi gratuita, por pertencerem a profissões liberais ${ }^{119}$. As suas funções, que se consideravam muito dignas, estavam ligadas à amicitia e, por isso, não podiam constituir objecto duma locatio operarum ${ }^{120}$.

Porém, na prática o beneficiado passou a abonar espontaneamente aqueles serviços, sem, todavia, se falar de salarium ou merces, mas de honorarium, remuneração que não afastava o seu carácter gratuito ${ }^{121}$. E este significado especial dum serviço prestado com base na amicitia estava tão firme na sociedade romana que, segundo parece, Augusto terá confirmado a proibição do salarium com a pena do quadruplum ao advocatus transgressor ${ }^{122}$.

Porém, foi-se impondo a necessidade de remunerar os serviços prestados pelos advogados. Nem todos tinham suporte económico que permitisse a sua sobrevivência e, ademais, sentiu-se que o custo da sua formação devia ser compensado. Por isso, Cláudio considerou legítimo o pagamento de honorários e estabeleceu um limite máximo $^{123}$. E Nero configurou este pagamento como verdadeira obrigação ${ }^{124}$, permitindo que se pudessem demandar os beneficiados com uma actio. No entanto, o juiz devia estimar em dinheiro os honorários, atendendo ao valor do litígio, à eloquência desenvolvida e ao costume do foro ${ }^{125}$. Foram proibidos os pactos que substituíssem os honorários por uma retribuição dependente da sorte do litígio ${ }^{126}$.

Nos finais do século III é manifesta a transformação da ajuda amistosa numa profissão especial de carácter público, sujeita à disciplina do magistrado jurisdicente e organizada em associações (collegia): o juiz pode aplicar multas, suspender e decretar o abandono do $\operatorname{cargo}^{127}$.

${ }^{119}$ Cf. D. 50,13,1. Vide SANTOS JUSTO, Direito privado romano - II (Direito das obrigações) 2 em Studia Iuridica 76 (Coimbra Editora / Coimbra, 2006) 70.

${ }^{120}$ Vide SANTOS JUSTO, Direito privado romano - I, cit. 286.

${ }^{121}$ Vide SANTOS JUSTO, ibidem, 286-287.

${ }^{122}$ Cf. DIO CASSIUS 54,18.

${ }^{123}$ Cf. TÁCITO, Annales 11,7.

${ }^{124}$ Cf. SUETÓNIO, Nero 17.

${ }^{125}$ Cf. D. 50,13,1,10.

${ }^{126}$ Os principais pactos eram: o pactum de quota litis, que permitia ao advogado receber uma percentagem do valor do litígio; o palmarium, através do qual o advogado só recebia os honorários se a sentença fosse favorável; e a redemptio litis, em que o advogado substituía o cliente no resultado do litígio e, por isso, se a sentença fosse desfavorável, respondia por ela. Note-se que a assunção do risco fazia subir excessivamente os honorários. Cf. D. 50,13,1,12; -17,1,6,7. Vide SANTOS JUSTO, ibidem 2871517

${ }^{127}$ Vide SANTOS JUSTO, ibidem 287. 
Quanto aos jurisconsultos cultores da iuris scientia, não se lhes permite que recebam honorários porque, refere Ulpianus, "a sapiência civil é uma coisa santíssima e não pode ser estimada em dinheiro nem desonrada". Todavia, considerou honesto recebê-los, ainda que fosse desonroso exigi-los ${ }^{128}$.

Mais tarde, a escassez de jurisconsultos determinou que, na prática, se eliminasse a antiga diferença entre jurisconsulto e advogado ${ }^{129}$.

\section{CONCLUSÕES}

É, agora, possível, extrair algumas conclusões acerca da administração da justiça no âmbito do processo da extraordinaria cognitio que, tendo surgido para resolver situações muito específicas, não tardou a impor-se como processo normal do direito romano:

$1^{\text {a }}$. A substituição do antigo processo das fórmulas traduz o abandono da administração da justiça por um (ou mais) juiz privado, embora actuasse sob a vigilância do Estado, através do pretor. Doravante, a administração da justiça é considerada função pública.

$2^{a}$. Esta transformação teve diversas consequências:

a) as despesas com a justiça passaram a ser pagas pelas partes e, muito particularmente, pela parte vencida;

b) abriu-se a possibilidade de uma cadeia de recursos sucessivos para os magistrados hierarquicamente superiores até ao Imperador. Tais recursos constituíam garantias de independência e imparcialidade, a que se juntavam a possibilidade de o magistrado-juiz incorrer na prática de um quase-delito e de graves sanções penais como a morte e o desterro.

$3^{\text {a }}$. Em relação aos advogados, os seus serviços não eram remunerados por se entender que, na sua base, havia uma relação de amizade que, considerada res inaestimabilis, não tinha preço. No entanto, necessidades várias impuseram a sua remuneração, não como preço (salarium ou merces), mas como honorarium, espécie de compensação ligada à honra de tais funções. E a elevação do processo a função pública produziu algumas consequências:

\footnotetext{
${ }^{128} \mathrm{~V}$ Cf. D. 50,13,1,5.

${ }^{129}$ Vide SANTOS JUSTO, ibidem 288.
} 
a) os advogados passaram a ser controlados pelos magistrados-juízes que estimavam o valor dos honorários e aplicavam a lei que proibia os pactos que os substituíssem;

b) surgiram as associações de advogados com membros fixos e supranumerários: aqueles podiam actuar em qualquer tribunal; estes, só em tribunais inferiores. Só podia inscrever-se quem fosse formado em Direito. E os seus membros tinham o dever de residência e perdiam os seus lugares por ausência superior a cinco e três anos, respectivamente, com e sem autorização do juiz.

$4^{\mathrm{a}}$. As execuções de âmbito patrimonial e pessoal mantiveram-se. Porém, a execução patrimonial podia, agora, incidir sobre a própria coisa (in natura) e sobre a pecunia correspondente à prestação do demandado. E a execução pessoal só funcionava se, tendo bens, o devedor não os cedesse aos credores ou não pedisse uma moratória para pagar as dívidas durante cinco anos.

Estas marcas da extraordinária cognitio da época justinianeia do direito romano, a que não é alheia a influência do Cristianismo, mostram um processo moderno, profundamente humanizado. Por isso, não pode surpreender que as suas raízes tenham invadido os nossos direitos.

5. Destas breves notas retira-se uma última conclusão: a administração da justiça é, no direito romano, uma coisa tão séria, que os Romanos chamaram sacrum auditorium aos tribunais e elevarem a justiça à dimensão divina. Por isso, chamaram divinos aos juízes e à iurisprudentia, a ciência do justo e do injusto, tendo por pressuposto o conhecimento de certas coisas divinas e humanas. Permitiram que os litigantes resolvessem os litígios mediante juramento. E obrigaram juízes, demandantes, demandados e advogados a prestar juramento perante os Santos Evangelhos de que actuariam no respeito pela justiça.

Hoje, a sociedade laicizou-se e a divindade foi substituída pela honra, valor que interessa defender e preservar. E, porque é uma coisa valiosíssima, invoca-se como garantia de conduta processual.

Porém, o princípio só mudou de nome: a honra faz parte do santuário dos homens e, portanto, constitui elemento nuclear da sua dignidade. Por isso, se invoca como suporte da justiça. 